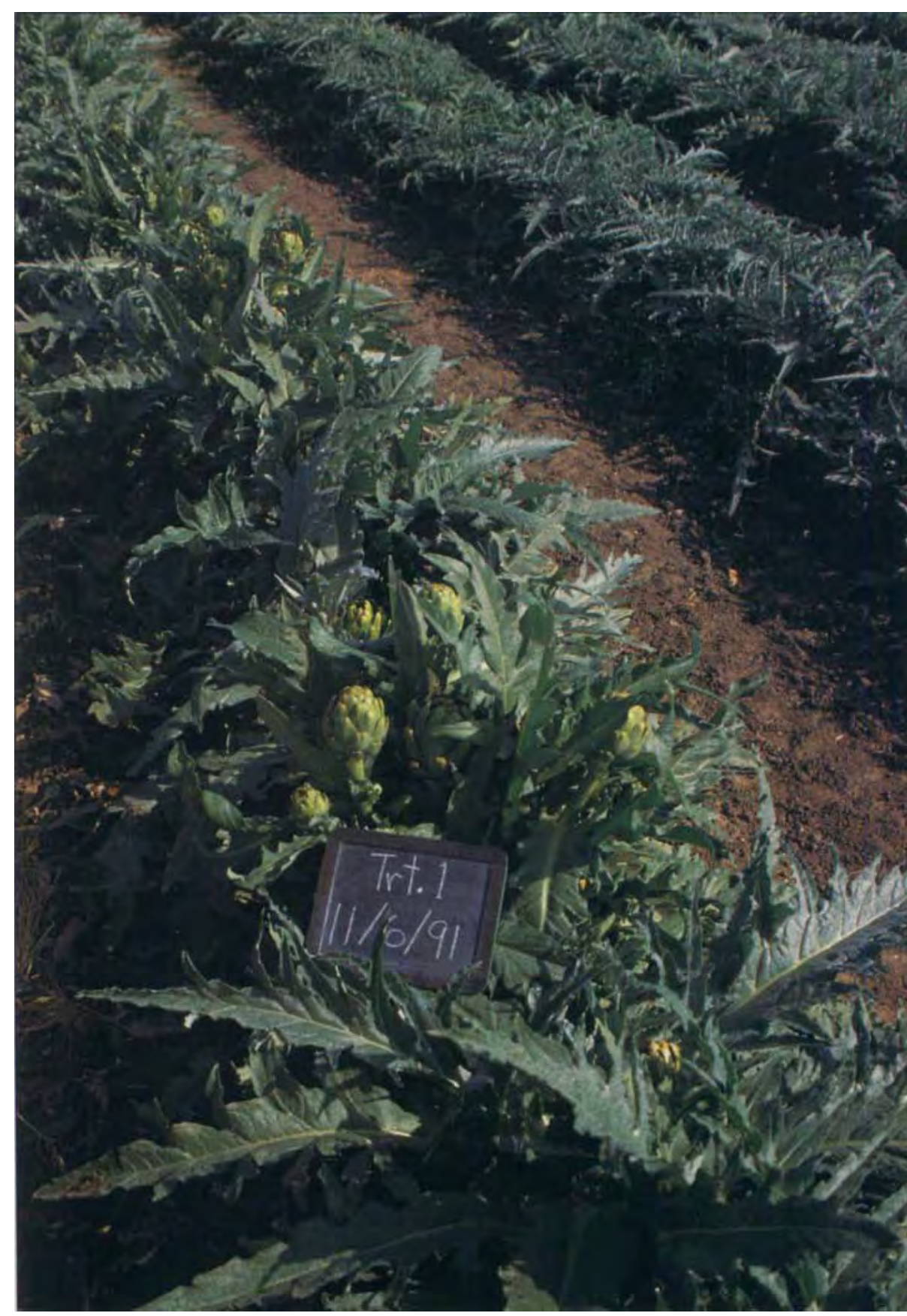

Comparison of plot treated with $\mathrm{GA}_{3}$ at $20 \mathrm{ppm}$ starting 4 weeks after transplanting (left foreground) and an untreated border row (adjacent right background) at first harvest on November 6, 1991 (trial 3).

\section{Growth regulator gives earlier harvest in artichokes}

Wayne L. Schrader
Southern California growers raise artichokes from seed as annuals for a winter harvest to take advantage of the favorable winter market prices. However, this method of production ties up fields for 9 months because the plants mature at different times. Now trials have revealed that multiple applications of gibberellic acid produce an earlier and more uniform first harvest in annual artichokes.

In California's central coastal region, growers produce globe artichokes as perennials, obtaining two distinct harvests each year by cutting plants back slightly below ground level in May, then letting them grow out for harvesting from August to April, or cutting back in September for harvesting from April to July. However, the Central Coast's cool winter weather sharply curtails yields between November and March.

In contrast, Southern California's coastal growers raise artichokes as annuals, starting from seed and taking advantage of the warm winter climate and favorable winter market prices. Seeds sown in May or June produce transplants that are moved to fields in July or August; harvesting begins in November or December and continues through March. The lack of uniform plant maturity and flowering in seeded artichoke fields extends the harvesting period.

If Southern California growers could compress the time between transplanting and first harvest, it would reduce their production costs. In addition, more uniform flowering would make it easier to target favorable market windows, lower the number of harvests required and free up the field for other uses.

Gibberellic acid $\left(\mathrm{GA}_{3}\right)$ is registered for use in perennial artichoke production to accelerate maturity and shift the first harvest to an earlier date. $\mathrm{GA}_{3}$ is currently applied to perennial artichokes in a single application 12 weeks after transplanting ( 6 weeks before the expected first harvest), at 10 grams of active ingredient per acre ( $10 \mathrm{~g}$ ai $/ \mathrm{ac}$ ) diluted in 100 to $125 \mathrm{gal}$ of water. 


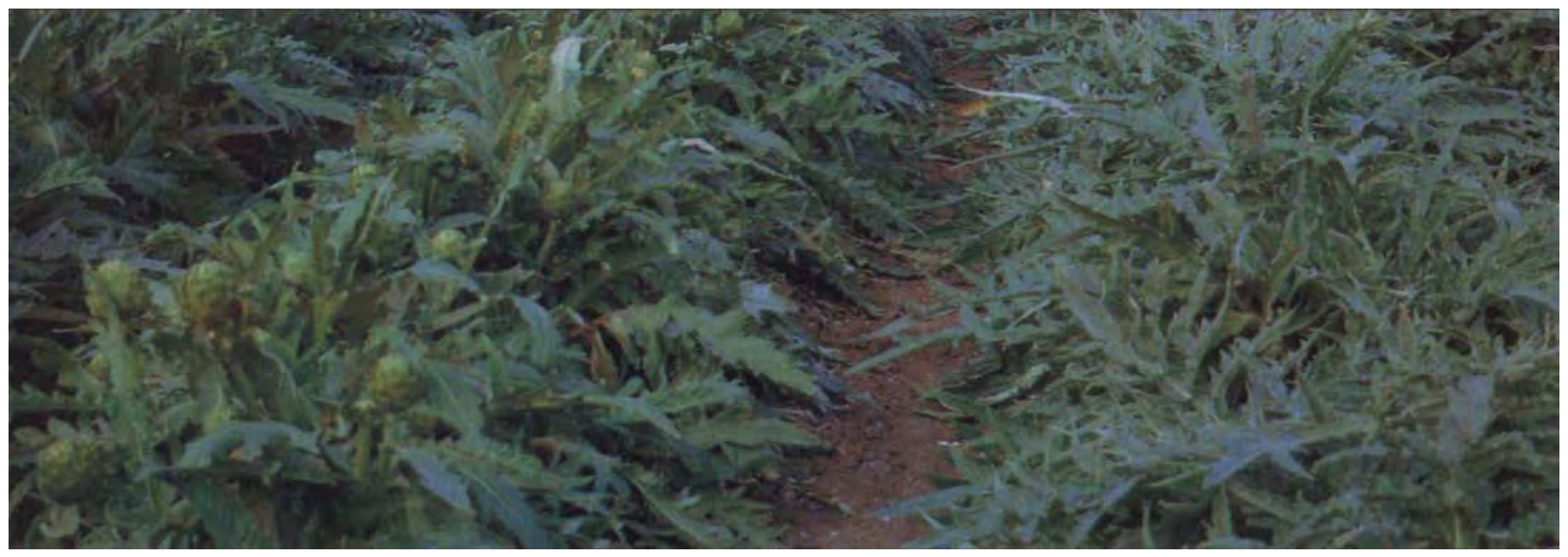

Comparison of sections of a commercial annual artichoke field treated with $\mathrm{GA}_{3}$ at $20 \mathrm{ppm}$ starting 6 weeks after transplanting (left side) and untreated rows (right side) near first harvest on November 3, 1992.

Annual artichoke production is a relatively recent addition to Southern California agriculture. Little is known about the effects of plant growth regulators on flowering in annual artichokes. According to field observations, the single application of $\mathrm{GA}_{3}$ developed for perennial artichoke production increased earliness slightly, but failed to achieve the level of uniformity and earliness desired for annual artichoke production. The current research was undertaken to determine which growth regulators, rates and application times were effective for accelerating maturity and increasing uniformity of flowering in artichokes grown as annuals from seed.

Experimental plant growth regulators were excluded from this research because new growth regulators are extremely difficult to register in minoruse crops. Multiple applications at 2week intervals were used because of the variable physiological plant age that is inherent within seeded annual artichoke fields. Treatments were initiated at different times during the season because the effectiveness of growth regulators depends heavily on correctly timing applications according to the plant's physiological age.

\section{Field experiments}

The effects of foliar plant growth regulator treatments were evaluated in three research trials using the randomized complete block design with four replications. The trials were carried out at the University of California's South Coast Research and Extension
Center in Irvine during 1990 and 1991. Artichoke seed of the cultivar 'Imperial Star' was planted in transplant trays on May 23, 1990 (trial 1); June 19, 1990 (trial 2); and June 4, 1991 (trial 3). Seedlings were transplanted to dripirrigated fields on July 11, 1990 (trial 1), and on August 1 in 1990 and 1991 (trials 2 and 3 ).

All field station trials had 80-inch beds and 24-inch in-row spacing. The single-row plots, which were $60 \mathrm{ft}$ long and located between common border rows, received a preplant application of monoammonium phosphate (11-48-0) at $450 \mathrm{lb} / \mathrm{ac}$ in two bands 6 inches apart and 4 inches under the plant row. Plants were set with sprinkler irrigation, and weekly drip irrigation applications of nitrogen (ammonium nitrate $20 \%$ ) were made at $10 \mathrm{lb} / \mathrm{ac}$ beginning 1 week after transplanting. Tensiometers - placed 6, 12 and 18 inches deep in the plant rows - were used to schedule irrigations and monitor leaching in the drip-irrigated trials.

The 1990 trials were designed to evaluate plant growth regulators applied either late in the season at the application time suggested for perennial artichoke plantings (trial 1) or earlier in the season (trial 2). Trial 1 began 12 weeks after transplanting ( 6 weeks before the expected first harvest) and consisted of the following treatments: (1) $\mathrm{GA}_{3}$ at $20 \mathrm{ppm}$; (2) $\mathrm{GA}_{3}$ at $40 \mathrm{ppm}$; (3) $\mathrm{GA}_{4+7}$ at $20 \mathrm{ppm}$, plus 6-benzyladenine, i.e. cytokinin (CK), at $20 \mathrm{ppm}$; and (4) control plots where no growth regulators were applied. These same treatments were used in trial 2, but ap- plications began 9 weeks after transplanting (9 weeks before the expected first harvest).

Trial 3, conducted in 1991, focused on finding the best time for starting the applications. All foliar treatments were made with $\mathrm{GA}_{3}$ at $20 \mathrm{ppm}$, applied for the first time $4,6,8,10$ or 12 weeks after transplanting. Each treatment was applied three times at 2week intervals. Control plots that received no growth regulator treatments were used for comparison.

Using a $\mathrm{CO}_{2}$ backpack sprayer, foliar applications were made at $15 \mathrm{gal} /$ ac with one nozzle per plant row for treatments that began 4 and 6 weeks after transplanting; and at $30 \mathrm{gal} / \mathrm{ac}$ with two nozzles per plant row for treatments that began later in the season. Early treatments required fewer gallons per acre because of the smaller plant size. In the earliest two applications (at 4 and 6 weeks), the plants were sprayed until the leaves were dripping to obtain full foliar coverage. In later applications, the foliar spray was directed toward the center of the plant and the growth point, and full coverage was not obtained.

The foliar applications at $20 \mathrm{ppm}$ made 4 and 6 weeks after transplanting required $1.1 \mathrm{~g}$ of $\mathrm{GA}_{3}$ ai/ac. By comparison, applications made 8 weeks after transplanting or later required $2.2 \mathrm{~g}$ of $\mathrm{GA}_{3}$ ai/ac. The total amount of $\mathrm{GA}_{3}$ applied per acre for the entire treatment (all three applications) depended on the date of the first application. The total amount was 4.4 and $5.5 \mathrm{~g} \mathrm{GA}_{3}$ a.i./ac for the treat- 
ments started 4 and 6 weeks after transplanting; it was $6.6 \mathrm{~g} \mathrm{GA}_{3} \mathrm{ai} / \mathrm{ac}$ for treatments begun 8 or more weeks after transplanting. Average plant diameter at these dates was 10,20 and 30 inches, respectively, in both years.

\section{Earliness and yield}

In trials 1 and 2, we evaluated earliness before the expected first harvest by counting the number of plants per plot having bud development that could be observed without moving the leaves (table 1). Foliar gibberellic acid treatments in trial 1, applied 12 weeks after transplanting (or 6 weeks before the expected first harvest, the application time suggested for perennial artichoke plantings) failed to bring about significantly earlier bud development. By comparison, the same treatments carried out earlier in the season in trial 2 (9 weeks after transplanting, or 9 weeks before the expected first harvest) significantly improved earliness, as shown in table 1 . In trial 2 the higher rate of $\mathrm{GA}_{3}$ (at $40 \mathrm{ppm}$ ) gave significantly more early bud development than $\mathrm{GA}_{3}$ at $20 \mathrm{ppm}$. $\mathrm{GA}_{3}$ was also more effective than $\mathrm{GA}_{4+7}+$ cytokinin in increasing earliness in this trial. Plots treated with $\mathrm{GA}_{4+7}+$ cytokinin did, however, yield significantly more early flower development than the control plots, where no growth regulators were applied.

First harvesting of treated plants in trials 2 and 3 began when buds

TABLE 1. Number of plants with observable bud development per plot in 1990 (trials 1 and 2)

\begin{tabular}{lcc}
\hline \hline & \multicolumn{1}{c}{ Timing of first treatment 12 and 9 weeks after transplanting* } \\
\cline { 2 - 3 } Treatment & 6 a & 9 weeks(trial 2) \\
\hline $\mathrm{GA}_{3}$ at $40 \mathrm{ppm}$ & $6 \mathrm{a}$ & $29 \mathrm{at}$ \\
$\mathrm{GA}_{3}$ at $20 \mathrm{ppm}$ & $6 \mathrm{a}$ & $23 \mathrm{~b}$ \\
$\mathrm{GA}_{4+7}$ at $20 \mathrm{ppm}+\mathrm{CK}$ at $20 \mathrm{ppm}$ & $5 \mathrm{a}$ & $6 \mathrm{c}$ \\
$\mathrm{Control}$ & $\mathrm{d}$ & $1 \mathrm{~d}$ \\
\hline
\end{tabular}

"Observations of trials \#1 and \#2 were made on November 14 and November 28, 1990, respectively. †Values in a column followed by the same letter are not significantly different at the $5 \%$ level.

TABLE 2. Number of marketable* buds harvested $\dagger$ per plot in seeded artichokes treated 9 weeks after transplanting in 1990 (trial 2)

\begin{tabular}{lccc}
\hline \hline Treatment & $\begin{array}{c}\text { Early yield } \\
\text { all sizes }\end{array}$ & $\begin{array}{c}\text { Total yield } \\
\text { all sizes }\end{array}$ & $\begin{array}{c}\text { Total yield } \\
\text { XLg+Lg } \$\end{array}$ \\
\hline $\mathrm{GA}_{3}$ at $40 \mathrm{ppm}$ & $179 \mathrm{af}$ & $540 \mathrm{a}$ & $144 \mathrm{a}$ \\
$\mathrm{GA}_{3}$ at $20 \mathrm{ppm}$ & $148 \mathrm{~b}$ & $544 \mathrm{a}$ & $144 \mathrm{a}$ \\
$\mathrm{GA}_{4+7}+\mathrm{CK}$ at 20ppm ea. & $70 \mathrm{c}$ & $457 \mathrm{~b}$ & $137 \mathrm{a}$ \\
$\mathrm{Control}^{-16 \mathrm{~d}}$ & $344 \mathrm{c}$ & $118 \mathrm{a}$ \\
\hline
\end{tabular}

"Marketable defined as buds of acceptable shape with a base diameter of at least 2.75 inches.

†Harvesting began on January 2, 1991, and was completed on April 2, 1991. Six harvests were completed in all.

$\ddagger$ Early yield defined as buds cut during the first three harvests, which were completed on February $1,1991$. §Yield of extra-large + large buds ( $>3.5$ inches in diameter).

IValues in a column followed by the same letter are not significantly different at the $5 \%$ level.

TABLE 3. Number of marketable* buds harvested $†$ per plot in 1991 (trial 3)

\begin{tabular}{cccc}
\hline \hline $\begin{array}{c}\text { Treatment } \\
\text { timing }\end{array}$ & $\begin{array}{c}\text { Early yield } \\
\text { all sizes }\end{array}$ & $\begin{array}{c}\text { Total yield } \\
\text { all sizes }\end{array}$ & $\begin{array}{c}\text { Total yield } \\
\text { XLg+Lg }\end{array}$ \\
\hline 4 weeks & $123 \mathrm{a \#}$ & $173 \mathrm{a}$ & $73 \mathrm{a}$ \\
6 weeks & $71 \mathrm{~b}$ & $170 \mathrm{ab}$ & $50 \mathrm{~b}$ \\
8 weeks & $41 \mathrm{bc}$ & $164 \mathrm{ab}$ & $37 \mathrm{bc}$ \\
10 weeks & $20 \mathrm{bc}$ & $153 \mathrm{ab}$ & $36 \mathrm{bc}$ \\
12 weeks & $8 \mathrm{c}$ & $115 \mathrm{~b}$ & $31 \mathrm{bc}$ \\
Control & $3 \mathrm{~d}$ & $53 \mathrm{c}$ & $16 \mathrm{c}$ \\
\hline
\end{tabular}

"Marketable defined as buds of acceptable shape with a base diameter of at least 2.75 inches. tHarvesting began on November 6, 1991, and was completed on February 21, 1992. Eight harvests were completed in all.

‡Weeks after transplanting when multiple foliar applications of gibberellic acid (GA $)$ at 20ppm began. §̧Early yield defined as buds cut during the first five harvests which were completed on January 8, 1992. IYield of extra-large + large buds ( $>3.5$ inches in diameter).

\#Values in a column followed by the same letter are not significantly different at the $5 \%$ level. reached optimal size and maturity as gauged by outward appearance, internal coloration and pappus development. This occurred on January 2 , 1991, for trial 2 and November 6, 1991, for trial 3. Because its earliness was not significant, trial 1 was not harvested. Plants were harvested at 1 - to 3-week intervals depending on the weather. Harvested buds were graded by diameter into four size classifications: extra large, or more than 4 inches (18 or 24 artichokes per carton); large, or 3.5 to 4 inches ( 36 per carton); medium, or 3 to 3.5 inches (48 per carton); and small, or 2.75 to 3 inches (60 per carton). Buds smaller than 2.75 inches in diameter were not counted. Data were analyzed by analysis of variance and Duncan's multiple-range test for treatment means.

According to yield data from trial 2 (table 2), the higher rate of $\mathrm{GA}_{3}$ gave a significantly greater early yield than the lower rate, but it failed to produce a higher total yield or a higher number of large buds. $\mathrm{GA}_{3}$ alone was more effective than $\mathrm{GA}_{4+7}+$ cytokinin for increasing earliness and total yield in seeded artichokes where treatments started 9 weeks after transplanting. However, plots using $\mathrm{GA}_{4+7}+$ cytokinin did produce significantly more early harvestable buds and a greater total yield than the control plots, where no growth regulators were applied.

According to yield data from trial 3 (table 3), three foliar applications of $\mathrm{GA}_{3}$, applied at 20 ppm at 2-week intervals, beginning from 4 to 12 weeks after transplanting, increased early and total yields compared to control plots, where no growth regulators were applied. The applications begun 4 and 6 weeks after transplanting also increased the yield of extra-large and large buds harvested. In general, the earlier the applications began, the earlier the harvest and the greater the yields.

Applications started 4 weeks after transplanting produced the highest yields of all. Applications begun 6 weeks after transplanting were less effective and resulted in significantly lower increases in early yield as well as lower yields of large and extra-large 


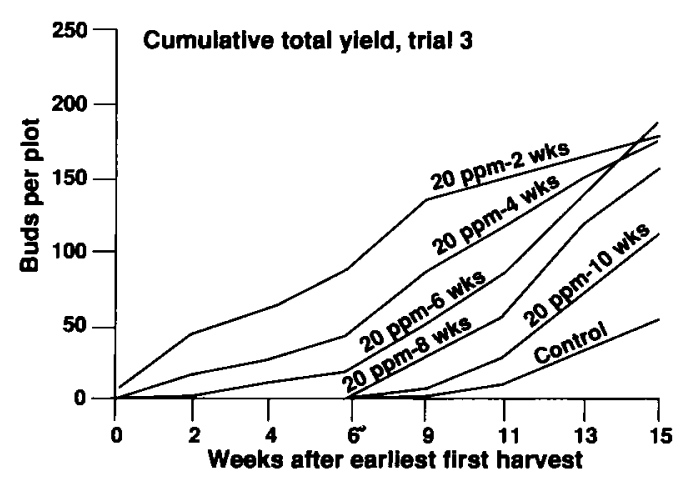

Fig. 1. Effects of the timing of gibberellic acid $\left(\mathrm{GA}_{3}\right)$ treatments on cumulative yield and earliness (trial 3).

buds. The yields achieved with treatments started 6 weeks after transplanting were numerically but not significantly greater than yields for treatments beginning 8 or 10 weeks after transplanting. Treatments begun 12 weeks after transplanting gave an early yield that was significantly lower than treatments begun 6 weeks after transplanting, but greater than the yield in the control plots. All of the $\mathrm{GA}_{3}$ treatments in trial 3 gave significantly higher early and total yields than the control plots. As cumulative yield data for trial 3 show (fig. 1), gibberellic acid treatments resulted in first harvests up to 8 weeks earlier than the control plots, where no growth regulators were applied.

In 1992, unreplicated $\mathrm{GA}_{3}$ treatment strip tests were conducted in a commercial annual artichoke planting of the cultivar 'Imperial Star' to see if fewer than three applications would be effective in achieving the earliness produced by early treatments in trial 3 . Treatments similar to those applied in trial 3 were applied at $20 \mathrm{ppm}$ starting 6 weeks after transplanting. There were one, two and three applications, with the multiple applications spaced at 2-week intervals. The results indicated that two treatments at $20 \mathrm{ppm}$ applied 2 weeks apart and totaling 4.4 grams of $\mathrm{GA}_{3}$ ai/acre may be sufficient to increase earliness and give the added uniformity desired for the first harvest, with less damage to the plants.

\section{Growth and vigor}

Plant responses to early $\mathrm{GA}_{3}$ treatments were striking in annual arti- choke production. The treated plants became more erect immediately after treatment and appeared to be larger than the untreated plants, which remained more prostrate. The treatments that gave the earliest first harvest were in full production 2 months ahead of the untreated control plots.

However, observations made during the research trials suggest that $\mathrm{GA}_{3}$ applications can negatively affect plant vigor, susceptibility to black tip and spider mite damage. Black tip on immature buds, elongation of early buds (causing early buds to be more conical than the normal globe shape) and susceptibility to mite damage increased when $\mathrm{GA}_{3}$ was applied at the higher $40 \mathrm{ppm}$ rate in 1990 . Although the bud elongation and black tip were not severe with $40 \mathrm{ppm}$ treatments, the $20 \mathrm{ppm}$ treatment was selected for use in subsequent trials.

The earliest 20 ppm GA $\mathrm{A}_{3}$ treatment, which started 4 weeks after transplanting in 1991, produced brittle leaves and some phytotoxicity in young plant tissue. Plants damaged in this way appeared to "grow away" from the damage early in the season, but decreased plant size and vigor as well as increased mite damage became apparent late in the production season. If harvesting had been continued for a longer period in spring 1992, the loss of vigor associated with the earliest $\mathrm{GA}_{3}$ applications might have reduced total yield, compared to yield in untreated plots or plots receiving later treatments.

\section{Interpreting yield increases}

Yield increases associated with $\mathrm{GA}_{3}$ treatments in these trials were due, at least in part, to the earlier production brought about by the treatments and the winter market's limited harvest period. Because of the negative impact on plant vigor of $\mathrm{GA}_{3}$ applied early in the season, total potential yield may actually have been reduced by the treatments.

Multiple applications of $\mathrm{GA}_{3}$ at 20 ppm starting 4 to 6 weeks after transplanting significantly increased earliness in annual artichoke production. These treatments shortened the time from transplanting to first harvest by 6 to 8 weeks. Treatments applied 10 or more weeks after transplanting failed to give the earliness and uniformity of first harvest that is desired for commercial production.

According to trial results, which were supported by tests made in commercial fields in 1992, $\mathrm{GA}_{3}$ foliar spray applications are effective in increasing earliness and uniformity of bud development in annual artichoke production without significant damage to plant development or economic yield. Research and field observations suggest that a growth regulator program for increasing earliness in annual artichoke production should consist of two or three foliar sprays of $\mathrm{GA}_{3}$ at 2week intervals applied at $20 \mathrm{ppm}$ and $30 \mathrm{gal} / \mathrm{ac}$ (a total of no more than $6.6 \mathrm{~g}$ of $\mathrm{GA}_{3} / \mathrm{ac}$ ), starting 5 to 7 weeks after transplanting when the plants average 18 to 25 inches in diameter.

Fields should be treated in four separate blocks or sections with applications starting (1) 5 weeks after transplanting in the first block; (2) 6 weeks after transplanting in the second block; and (3) 7 weeks after transplanting in the third block. The fourth block should receive no treatment if transplanting was started early enough for flowering to begin during the middle of the targeted production period. Following this schedule should deliver large-size, high-quality bud production over the entire targeted production period. $\mathrm{GA}_{3}$ should not be applied during periods of high temperature. The effects of multiple applications of $\mathrm{GA}_{3}$ applied early in the season on perennial plantings of green globe artichokes cannot be predicted based on the results of these trials in annual artichoke production.

Abbott Laboratories is currently pursuing a modified label for their $\mathrm{GA}_{3}$ product that would allow this new application format in annual artichoke production.

Wayne L. Schrader is Farm Advisor, San Diego County Cooperative Extension, University of California.

The author wishes to thank Abbott Laboratories for helping to fund this research and Murai Farms for their support in the field research trials. 